\title{
PAST AND PRESENT ISSUES OF JAVANESE-EUROPEAN MUSICAL HYBRIDITY: GENDHING MARES AND OTHER HYBRID GENRES
}

\section{Sumarsam}

The history of Indonesia encompasses a succession of interactions with foreign cultures. Hindu, Islamic and Western cultures, in particular, have had the most significant impact on the development of Indonesian culture. Trade, followed by religious conversion and colonization, characterize the course of Indonesian history. The interactions have influenced the growth of Indonesian cultural tradition considerably; a growth epitomized by localizing and hybridizing foreign elements.

The development of music and musical culture in Indonesia also followed this general scheme. Whereas each of the Indonesian regions has a distinct socio-cultural tradition, the interactions have produced a rich variety of localized/hybridized forms of Indonesian music.

This chapter ${ }^{1}$ focuses on the development of gendhing mares ${ }^{2}$ ('marching' gamelan pieces) ${ }^{3}$ in the court of Yogyakarta. Gendhing mares requires the incorporation of European brass instruments and drums and is used to accompany the exit and entrance of serimpi, one of the most refined dances in the court of Yogyakarta. Aside from the sound structure of the music, this chapter addresses the history and meaning of the genre. In so doing, I will take into account other hybrid genres, in particular tanjidor and certain contemporary music genres.

Following Geertz's explication of the meaning of symbolic action (Geertz 1973: $363-364)$, Rice sees the importance of understanding the 'formative

\footnotetext{
1 I would like to thank Prof. Margaret Sarkissian of Smith College for her comments and suggestions.

2 Mares is derived from the Dutch mars (march). During the Japanese occupation (1942-1945) the use of the Dutch words was suppressed and so the word gati was used (Subuh 1986). Gati is a Sanskrit-based Old Javanese word, which means, among other things, 'coming' and 'to be in motion' (for example, magati) (Zoetmulder 1982: 500-501). In modern Javanese, it also connotes a sense of 'important' (for example, wigati) and 'in a hurry' (for example, gati-gati). I would like to thank Els Bogaerts for her suggestion to trace the etymology of the word gati and its relevance as a substitute for the term mares.

3 Gendhing means gamelan composition.
} 
processes' in music in terms of how people historically construct, socially maintain and individually create and experience music (Rice 1987: 473). This is, indeed, an important and encompassing perspective. Viewed from this perspective, gendhing mares becomes an intriguing subject of inquiry. In the first place, the genre was composed during the time when Javanese courts became vassals of the Dutch colonial government, signifying a complicated power (im)balance between the two sides. The fact that this genre was used to accompany serimpi dance - an important cultural expression of the concept of alus (refinement), one of the hallmarks of the Javanese world view - means that the symbolic meaning of gendhing mares deserves closer investigation. The issue becomes even more intriguing given the fact that, more recently, gendhing mares has been used to accompany the entrance and exit of the dancers of the most sacred and refined ceremonial dance in the court of Yogyakarta, bedhaya Semang.

This leads us to a series of pertinent questions: if we believe that the gamelan ensemble was 'endowed with a special aura that forged the link to figures of authority' (Becker 1988: 385), and that bedhaya and serimpi ceremonial dances are considered emblems of the ruler's power, how do we explain the incorporation of European sounds into the gamelan ensemble? Is this incorporation a kind of Javanese-European intercultural sonic dialogue, a subversive act of European authority, or the domestication of an exotic sound? What was the thinking behind the use of gendhing mares to accompany bedhaya Semang in the context of a contemporary Indonesian musical scene?

\section{European Marching Bands in Java}

To address these questions, I would like to begin with a brief history of the European marching band in Java. Three types of Western music were introduced to Indonesia by the Portuguese in the 16th century: church, secular, and military music (Sumarsam 2001: 284-285). Slave musicians were instrumental in introducing these last two types of European music to the homes of rich European traders. Subsequently, European military bands flourished alongside the establishment of the Dutch East Indies Company in the seventeenth century. Thereafter, the localization of European music and the hybridization between European music and traditional Javanese music occurred. The 'Babad Giyanti' chronicle gives us a hint of Javanese-European hybrid music in the court of Kartasura in the eighteenth century. The poem describes a royal procession that 
moved the court capital from Kartasura to Surakarta in late 1745 or early 1746.4

Upon the appearance of the King,

the Dutch Company and the Javanese troops

saluted with a loud salvo,

and were answered by the great cannon's

shattering thunder.

The musicians (musikan) playing selompret (the trumpets), tambur (the drums), suling (flutes), bendhé (a hand-held gong) together with

the loud sounding of monggang, kodhok ngorèk, and

carabalèn gamelan, beautifully sounded.

Tumult was among the people of the capital. ${ }^{5}$

Slompret (trumpets) and tambur (drums) were European instruments, as confirmed by the word musikan, a term derived from the Dutch muzikant (musician, referring specifically to a European music troupe); ${ }^{6}$ suling and bendhe were Javanese instruments; hence, a hybrid music. Other passages confirm this hybrid practice, like the one mentioning that the Company's musicians jointly played the trumpets, drums, suling, bendhe, and kendhang. ${ }^{7}$ Most likely, suling in this passage refers to European fifes, while the last two instruments were clearly Javanese. Similar hybrid marching bands still exist in the courts of Yogyakarta and Surakarta. Groneman (1890: 80-87) mentions a number of them, including an ensemble consisting of a European drum, a pair of traditional wind instruments called puwi-puwi, two small kendhang, and one bendhe.

Other Javanese-European hybrid music involving brass band instruments can be found outside the courts of central Java. For example, a genre called tanjidor can be found on the outskirts of Jakarta. The term tanjidor is said to derive from a Portuguese word tangedor. According to Paramita Abdurachman (2008: 48), the root of the word tangedor is tanger, which means to play on musical instruments. She also says that tangedor

\footnotetext{
${ }^{4}$ For the difficulty determining the move of the capital court to Surakarta, see Soepomo Poedjosoedarmo and Ricklefs (1967: 89).

5 Dhandhanggula / Tedhakira kangjeng kang siniwi / pra prajurit kumpeni lan jawa / urmat drel atri swarane / sinauran mriyem gung / magenturan anggegeteri / slompret tambur musikan / suling bendhe barung / munggang kodhokngorekngangkang / cara balen pradangga munya ngrerangin / horeg wong sanagara (Yasadipura, quoted in Soepomo Poedjosoedarmo and Ricklefs 1967: 101). Javanese spelling and English translation have been adapted by the author of this chapter.

${ }^{6}$ I would like to thank Els Bogaerts for her suggestion of the origin of the word musikan.

7 Binarungan musikan kumpeni / slompret tambur suling bendhe kendhang (Soepomo Poedjosoedarmo and Ricklefs 1967: 103). Spelling adapted by the author.
} 
means a musician who plays a string instrument, usually outdoors. Subsequently, tangedor can refer to a brass band for accompanying military and religious processions. In the case of the ensemble called tanjidor in Indonesia, it is not well documented how, when, and in what context this music as we know it today developed.

The assumption is that tanjidor originated in the eighteenth century when leading European households in and around Batavia (now Jakarta) maintained civilian wind ensembles staffed by house-slaves or soldiers (Yampolsky 1994). Several authors have mentioned such slave orchestras in their writings (Boxer 1965; De Haan 1910/12; Van de Wall 1932; Haryadi et al. 1980). ${ }^{8}$ These orchestras performed European marches and dance tunes (waltzes) for the entertainment of their wealthy landowning masters. The life of Augustijn Michiels, an early nineteenth century estate owner in Citeureup (near Bogor), gives us a picture of music in the homes of wealthy European landlords. As reported by Doren (quoted in Van de Wall 1932), who visited Citeureup in 1822, this wealthy landowner liked to throw lavish parties for his guests, with a number of music genres performed for the occasion. He had four music ensembles in his household: a European ensemble, an army marching band, a Chinese ensemble, and a gamelan. ${ }^{9}$ Van de Wall notes that when Michiels died in 1833 , his family had to auction 30 slave musicians and their instruments. They included players of the clarinet, viola, trumpet, harp, horn, bassoon, bass, trombone, and drums. With a few exceptions, these instruments are pretty much the same as those used in contemporary tanjidor, although we do not know if the term tanjidor was already in use at the time.

When the institution of slavery and the era of lavish estates died out in the mid-ninteenth century, native Batavian musicians continued the tradition of band playing. This led to the development of a SundaneseEuropean hybrid ensemble as bands incorporated Sundanese musical instruments and repertoire. By the turn of the twentieth century, these bands functioned as street ensembles, playing in well-to-do neighbourhoods of Jakarta, especially during the Chinese and European New Year

8 The last reference, Haryadi et al. (1980), is a report of fieldwork on tanjidor carried out by a group of faculty members of the Jakarta Institute of Arts Education: Frans Haryadi, Yulianti Parani, Mona Lohanda, Siswandhi, and Suwandi Mangkudilaga. This is the most extensive report of the history, function, and musical practice of the genre.

${ }^{9}$ It is noteworthy that European music, gamelan, and Chinese music were present together in Michiels' house. Had musicians of these three genres exchanged their musical repertoire or idioms? Perhaps, but there is no evidence to support this assumption. 
celebrations. As the bands found employment accompanying various functions in villages on the outskirts of Jakarta, they began to play more Sundanese music. Interestingly, tanjidor musicians considered European marches and waltzes as signature pieces and played them as overtures to performances regardless of the performance context of the band (Haryadi et al. 1980: 103).

It appears that by the mid-ninteenth century, tanjidor became an established term for the brass band and its use spread to other parts of Java. In his chronicle 'Babad Krama Dalem', Atmadikrama (1865-1866: 61-62) describes the wedding celebrations of King Paku Buwana IX (r. 1861-1893) as follows: 'After the Dutch Resident offered a toast for the well-being of the marriage of the king, then they, who were in attendance at the celebration, replied 'hurrah' repeatedly and very boisterously. They all drank at the same time; the sound of tanjidhur honoured [the toasting] at once. Tanjidhur ended, and was followed by the soft sound of gamelan [....].' The poem continues, describing the last round of toasts in which the Resident called for words of safety for the land of Java. All the guests replied 'hurrah' and then stood up to disperse for eating, during which 'gamelan and tanjidhur were played. Gamelan Pelog, Slendro, and Senggani were played simultaneously [with tanjidhur] without pause [....].'

The simultaneous sounding of European musical instruments and gamelan described in the poem does not represent a syncretistic form of musical production since each ensemble performed in their own style and space. However, there is an example of a musical synthesis in the court of Yogyakarta that represents musical hybridity; namely, the gendhing mares. Although this genre is an exception within the Yogyakarta court, it has a prominent function.

As mentioned elsewhere (Sumarsam 1995), as social interaction between the Javanese courtiers and Europeans became a fact of life in Javanese courts, the band and other genres of European music were incorporated into their musical life. In addition to accompanying European social dances, the bands gradually began to accompany all sorts of court ceremonial events. For these reasons, Javanese courts had to maintain European ensembles, staffed by Javanese musicians under the tutelage of European bandmasters. It was in this atmosphere of Javanese-European social intercourse that gendhing mares emerged. The gendhing mares are all in the pelog tuning system, presumably because pelog is the closest tuning to the Western diatonic system (see the contribution by Wim van Zanten in this volume). 
The creation of gendhing mares is not well documented. Some leading musicians and dancers in the court of Yogyakarta have suggested that the genre was associated with gendhing sabrangan (Subuh 1986). ${ }^{10}$ The musicians also say that the use of the term gendhing mares - implying the beginning of the incorporation of brass band in the gamelan - occurred during the reign of Hamengku Buwana (HB) VII (r. 1877-1921) or HB VIII (r. 1921-1939) (Subuh 1986). Another musician suggests HB V (r. 1825-1855) was the creator of gendhing mares (Vetter 1986: 281).

The only evidence of the existence of gendhing mares is the 'Serat Pakem Wirama', a court manuscript containing a list of gamelan pieces, information about their use and a description of the instruments (Serat Pakem Wirama 1889). The manuscript, which was written, copied, and recopied from 1898 to 1921 (Lindsay 1991: 207), lists some thirty gendhing mares, But provides no specific information about the year in which the gendhing mares was listed. Indeed, we can only speculate that the genre was composed between the end of the ninteenth and the beginning of the twentieth century.

\section{Comparing Gendhing Mares and Tanjidor}

It is commonly thought that many incompatible musical elements (e.g. linear versus horizontal orientation, a cyclic versus a through-composed structure, and the particularities of the slendro-pelog tuning system) have kept gamelan and European music apart. However, the evidence provided by tanjidor and gendhing mares reveals that compatibility (or incompatibility) of musical systems should be discussed in conjunction with (a) social and political relationships between cultures and (b) the reactions of a particular society towards cultural and historical development. Furthermore, the distinctive style of particular hybrid music embodies the socio-historical significance of the region in which the music developed.

Tanjidor has passed through many different socio-historical contexts, from the eigteenth-century slave orchestra to Betawi music of the early twentieth century, and from entertainment for wealthy masters to military music, street music, and music for rites of passage. Throughout these evolutions, tanjidor was cultivated and developed by members of the

10 Sabrang means 'overseas'; sabrangan, 'the foreign one'. Sabrangan also refers to the name of the drumming pattern of some gendhing for accompanying the lance dance (lawung). All gendhing mares use sabrangan drumming. 
lower class (slave and native Betawi folk musicians). It is a kind of music that served emotional needs in their difficult lives. The result is a genre in which European musical instruments were domesticated by being played in an exuberant style of Sundanese music. The suppleness of tanjidor is commensurate with the character of folk music generally. Folk musicians are both skilled and creative artists in the true sense of the words - they have the flexibility to execute a piece of music in the most creative way possible. By examining two repeated cycles of a tanjidor piece, we can see the different ways in which the clarinet, helicon, and horn render the same melodic phrase by adding passing notes, lengthening principal notes, and altering rhythms. In addition, the clarinet, like the singer or the rebab in Sundanese gamelan, also defines this lively genre. The clarinet player shifts from one tuning system to another (from slendro to a pelog-like system) with ease by cleverly flattening certain notes. Elaborate drumming, whose rhythms directly related to animated dance movements, adds to the musical liveliness of tanjidor. In fact, tanjidor often accompanies a male dance party in which guests take turns dancing with professional female dancers.

In gendhing mares, we find a more limited contribution from European brass instruments and drums to the gamelan. The reason for this constraint lies in the choice of the treatment (garap) of the piece. Sundanese and Javanese gamelan compositions comprise several layers of melodic lines and are composed within a fixed formal structure (i.e. a gongan cycle). What is distinctive about Javanese court gamelan is the prominent execution of a steady, pulsed melodic skeleton (balungan) of a gendhing by a group of several saron (metallophones of various low and high octaves). In a certain playing style, the playing of the balungan produces very loud sound indeed, as the melodic skeleton is performed in unison by at least seven and as many as sixteen saron.

Another factor that determines whether a piece (or section of a piece) should be performed in a soft or loud playing style is the concept of irama. The irama involves the shifting of both temporal flow (fast, medium, and slow) and temporal space (the expanding and contracting of the gongan cycle accompanied by the rise and fall of density level of the elaborating instruments). There are four levels of irama: tanggung, dadi, wilet, and rangkep. Each irama determines both the playing style and the treatment of the melody for elaborating instruments: e.g. whether a piece should be played in soft or loud playing style. Gendhing mares is played in irama tanggung, in a loud playing style, featuring the balungan instruments and without the participation of soft-sounding, elaborating instruments. One 
repercussion of irama tanggung is that it constrains the melodic treatment of a gendhing. The absence of elaborating instruments does not allow the ensemble to project the kind of musical complexity that would be possible if these instruments were present playing elaborated forms of melodies.

One can only ask why European instruments were not engaged more actively in gamelan (as they were in tanjidor). An answer can be found in the historical and cultural background of gendhing mares, a history that revolves around the interactions between the Dutch colonial government and the courts in central Java. It follows that tolerating the presence of European music in their courts enabled Javanese rulers to demonstrate their acknowledgment of the political realities of the day - court life in the context of European colonialism.

What is intriguing is that gendhing mares appeared at a time when the conflict between Javanese courts and European colonialism had reached its peak. This is a period when, after much European interference in the state affairs of Javanese courts, and especially after the Javanese revolt in $1825-30$, true colonialism was established. According to Ricklefs, "[f ]or the first time the Dutch were in a position to exploit and control the whole island, and there was not to be any serious challenge to their dominance until the twentieth century' (Ricklefs 1993: 119). What was the reaction of Javanese royal culture toward the consolidation of colonial control in Java? One common interpretation is that, faced with political impotency, members of the royal family focused their energies inward towards cultivating and refining art and culture. ${ }^{11}$ In the words of Ricklefs (1993: 113), the Central Javanese courts 'became ritual establishments and generally docile clients of the Dutch'. This position, however, serves to ignore evidence of the dynamics of court culture during the domestication of nonJavanese elements. Pemberton (1994: 70) explains that it is:

[...] misleading to dismiss Central Javanese palaces from 1830 on simply as ritual establishments, as ornate signs of powerlessness or tokens of docility, no matter how docile their regal inhabitants might have been. Beyond the conventional historiographical point that Dutch rule in Central Java was maintained until the end through a typically colonial alliance with the indigenous aristocracy, the power of endurance exhibited by ritual

11 Commonly, historians point to the period after the permanent division of Mataram kingdom into two major courts and two minor courts in 1755 as the beginning of this inward looking activity of the courts. 
establishments, whether in the concrete form of the Kraton Surakarta, two hundred plus years, or in discursive form, "Java," is most ominous.

The reaction of Javanese courtiers to the penetration of colonial culture was to re-establish a well-ordered cultural landscape in the courts, taking into account outside elements by ritually situating the Dutch not as intruders, but as respected guests (Pemberton 1994: 69). In other words, both the presence and superiority of the Dutch were domesticated into Javanese court culture. Gendhing mares and other Javanese-European cultural hybrids were the products of this domestication. Musically, the European brass band in gendhing mares was fitted to the basic rules of gamelan composition while constraining melodic disposition, i.e. the treatment of irama tanggung with the absence of melodic elaboration. Yogyakarta court musicians, unlike the Betawi street musicians, were reluctant to incorporate fully European brass instruments into a gamelan ensemble. In any event, the fact that gendhing mares was created to accompany one of the most important royal cultural expressions, the serimpi dance, proves its powerful symbolic significance.

What has emerged from the two instances of hybrid musical practices described above is the heterogeneous nature of the localization process and its resulting European music. The process involves the roles of regional history, power relationships, and the attitudes of the musicians as shaped by historical and cultural circumstances. Oftentimes, this locally/ historically constructed hybrid music persists as a marker of regional identity. Even during the period of Indonesian independence, the music still lives on as a legacy and marker of a distinctive feature to a particular manifestation of the local.

Due to the development of other popular music in Indonesia, with which the band must compete, tanjidor has been marginalized in recent decades. This marginalization worsened in the 1950 s when the local government banned the bands from performing in front of stores along the streets of Jakarta. This was done, according to Yampolsky, because the mayor of Jakarta was displeased to see native Betawi musicians being treated like beggars by the Chinese (Yampolsky 1994). Abdurachman (2008: 48), however, says that the ban was imposed because the loud sound of the music disturbed people from their afternoon rest. Later the ban was relaxed, although the musicians had to seek letters of permission from the government. This rule caused the continuing marginalization of tanjidor. Nonetheless, the historic and distinctive features of the music make tanjidor one of the important Jakartan musical identities of today. 
Oftentimes the local government puts up workshops and symposia on tanjidor, assigning cultural activists, scholars, and performers to find ways to support and revitalize the genre.

\section{Gendhing Mares and the Reconstruction of Bedhaya Semang}

The current royal family of the Yogyakarta court only occasionally sponsors the performance of serimpi dance with the accompaniment of gendhing mares. As mentioned at the beginning of this chapter, a notable use of gendhing mares emerged in a recent project to reconstruct the most sacred ceremonial dance of a long-defunct, four-hour bedhaya Semang. This dance and its counterpart, the bedhaya Ketawang in the court of Surakarta, are considered the most sacred dances in their respective courts, the ruler's emblem of power, and the court's official insignia. Its connection with the story of the most powerful spiritual entity, the goddess of the Southern Ocean (Ratu Kidul) confirms the special status of this bedhaya (Hostetler 1982). ${ }^{12}$ The story goes that in preparation for becoming king, Sultan Agung had to become familiar with the true scope of his realm, including Ratu Kidul, the goddess of spiritual beings of considerable power and danger. ${ }^{13}$ The young Agung accompanied the goddess to her beautiful palace beneath the Southern Ocean. There, in the goddess's palace the bedhaya Semang was created for him. The mystery surrounding the origin of this bedhaya enhances the ethos of the power of this dance.

Bedhaya Semang had not been performed since the second half of the reign of Hamengku Buwana VII (1877-1921). In 1972, the court wanted to reconstruct the dance. The reconstruction failed to materialize, however, because of the lack of resources necessary for the project. Theresia Suharti, then a student of the Indonesian Art Institution (Akademi Seni Tari Indonesia, ASTI $)^{14}$ in Yogyakarta and also a court dancer, used the material of this reconstruction for her thesis. After Suharti became a faculty member of the institution and a senior teacher/dancer of the court in 2002, she became interested in continuing the reconstruction. Under the supervision of a 70-year-old court dancer/teacher, Bandara Raden Ayu

12 The following story is based on Hostetler's essay. She based the story of the origin of bedhaya Semang on the 'Serat Babad Nitik', a manuscript about Sultan Agung.

13 The myth from the court of Surakarta names Panembahan Senapati, the founder of Mataram and Sultan Agung's grandfather, as a figure who met Ratu Kidul, who created bedhaya Ketawang for him.

14 Now Institut Seni Indonesia, ISI. 
Yudanegara, she led the project. She gathered old documents about the dance and its music, organizing and leading rehearsals, and raising financial support from different agencies and individuals. She also wrote an article about the reconstruction process (Suharti 2002). The reconstruction was completed in 2006 and was performed before Sultan HB X and his families. It was properly documented in an audio and video format. As far as I know, there has not been another performance of this dance since the event in 2006.

In the course of the reconstruction, questions about musical accompaniment for the entrance and exit of the dancers surfaced. ${ }^{15}$ Should they be accompanied by a refined ladrang piece or gendhing mares? The ladrang piece was suggested by the musicians and dance teachers; the gendhing mares was the preference of a higher-ranking courtier. Eventually, the dance teachers and musicians had to accept the decision made by the high-ranking courtier; hence gendhing mares accompanied the entrance and exit of the dancers in the final performance in the presence of the Sultan. However, during the rehearsals, a refined ladrang piece was often used. The courtier in question was a young prince, who preferred gendhing mares because of its sigrak (lively) character.

I would suggest that, aside from the distinctive feature of gendhing mares as a Javanese-European historic/hybrid music, the choice of gendhing mares to accompany bedhaya Semang can be linked to a contemporary trend of gamelan music in Indonesia. This trend can be illustrated by discussing music performed in the Yogyakarta Gamelan Festival (YGF) and the music of campursari.

\section{Contemporary Hybrid Music}

Let me begin with the Yogyakarta Gamelan Festival. The sole organizer of the festival was the late Sapto Rahardjo (1955-2009), the programme director of Geronimo Radio station and, in the 1990s, a member of the Yogyakarta Arts Council. He was also a composer in his own right. The seed of the festival can be traced back to gamelan concerts in 1993 and 1994 at the annual Yogyakarta Art Festival (Festival Kesenian Yogyakarta, FKY). One aspect of the festival featured new compositions for gamelan by Cokrowasito, Wasisto Surjodiningrat, and Sapto Rahardjo himself.

15 The following account is based solely on my personal communication with Suharti in 2009 . 
In the following year, the festival presented the works of Ben Pasaribu, Slamet Abdul Sjukur, Djaduk Ferianto, and Sapto Rahardjo - all renowned Indonesian composers. In 1995, the gamelan part of the FKY was called Yogyakarta Gamelan Festival.

In spite of its name, the festival programme included non-gamelan music. Sapto explains this contradiction philosophically: 'gamelan is a spirit, not an object. The instruments are just the medium'. This statement became a motto of the festival. Beside performances, other related events, such as lectures, panel discussions, radio talk shows, and a special time slot for gamelan broadcasts from Sapto's radio station were part of the festival. Participants in the festival included groups and individuals from abroad. The groups came to the festivals with funding from their own institutions, state governments, or private institutions. The festival organizers only provided local accommodation.

Concerts in the YGF tended to be 'spectacular' presentations of various music genres: traditional gamelan, hybrid Western-traditional music, and new music for gamelan or other ensembles. They used a very elaborate sound system with large, multiple speakers, and two large screens for video projections on the left and right sides of the stage. Typically, the stage backdrops were very elaborate, employing billowing, machine-made smoke, fancy and colourful lighting, and sometimes slide projections.

The festival attracts a primarily young, urban, and educated audience interested in musical performances that feature traditional and Western elements in modern, hybrid synthesis. Traditional gamelan was not excluded from the festival, but presented as exceptional, featuring, for example, gamelan performances by very young children, gamelan groups from abroad, and a Javanese gamelan group from Singapore whose members consisted of Javanese people who have settled there during the past century. There were also traditional gamelan groups, such as a group from the Institute of the Arts in Yogyakarta, and groups from Yogyakarta or its vicinity, performing traditional pieces or kreasi baru (new creation). In any event, the festival tends to emphasize the presentation of musik kontemporer (new or experimental music) that conveys a hybrid character. It has become apparent from discussions and newspaper coverage that the most important reason for creating hybrid music is to overcome the dichotomy between so-called ethnic music and Western music. This is in line with the desire of younger generations among the audience who see the mixture as a way to modernize traditional gamelan.

From its debut to its demise after the death of Sapto Rahardjo in 2009, the YGF presented a repertoire that could broadly be categorized into 
three types: kreasi baru (new creations for gamelan drawn from traditional instrumentation and idioms); musik kontemporer or experimental music; and music that leans towards popular genres. More importantly, what emerged from the festivals was an emphasis on musical hybridity; namely, a mixture of different musical ensembles, idioms, and styles. To illustrate this point, I would like to discuss four influential Indonesian composers: Djaduk Ferianto, Sapto Rahardjo, Cokrowasito and Slamet Abdul Sjukur.

Djaduk Ferianto's ensemble Kua Etnika consists of a mixture of traditional musical instruments (including Balinese and Javanese gamelan), Western instruments, and sometimes certain 'non-musical' objects. A son of the well-known choreographer and painter Bagong Kussudiardja, Djaduk is a self-taught composer with an affinity to both traditional Indonesian and Western music genres. Typically, Kua Etnika's repertoire encompasses both the playful and serious character of his music. It often contains social commentary and criticism. The following statement from the group's liner notes conveys the concept and sensibility of Djaduk and his music:

A self-taught musician very familiar with ethnic music, Djaduk creates music that is based on a discipline called "ngeng": a traditional musical concept (i.e. sensitivity toward sound, pitch and rhythm), which is innate to any person. Ngeng is also used as "conditional mood" of the music. For Djaduk and his community, the potentiality of ngeng is an important factor in their treatment of the music. Ngeng also becomes an "abstract score" to be used for the basis of creating music.

The discipline of $n g e n g$ is then fused with the discipline of Nang Ning Nong, which is drawn from Balinese traditional music. Nang Ning Nong is a key word (i.e. sound/symbol) for the Balinese to teach and communicate melody. It is through Nang Ning Nong that the exploration of sound, tone, and rhythm evolves. Each musical instrument has potentials to form [a] structure of tones, rhythm and meaning. Nang Ning Nong is used for orientation, because in their musical exploration Djaduk and his friends use Balinese gamelan, along with Western music instruments, percussion and other objects [....] (Djaduk Ferianto 1997).

This quotation highlights the hybrid nature of Djaduk's conception of his music by combining three elements: Javanese sensitivity toward inner experience as manifested in the concept of 'ngeng'; the articulation of percussive sounds (Nang Ning Nong) of Balinese music; and his readiness to incorporate Western musical idioms. Additionally, Djaduk explicitly states that his music reflects the dynamics of society with which it tries to be in close contact. 
Because of the hybrid nature of its instrumentation, the ensemble can refer to different genres, such as gamelan music, jazz, rock, kroncong, and so forth, in the course of playing a piece. The point here is that, in creating new compositions, Djaduk explores traditional musical idioms and values. Other composers have followed in the same spirit: they cannot leave behind traditional music in creating their new works.

Sapto Rahardjo began performing Javanese gamelan and dance and rock music during his junior and high school years. He studied at the Yogyakarta academy of drama and film (Asdrafi). His position at the Geronimo Radio station gave him access to all sorts of new technology, including computers. A self-taught composer, his work conveys an amalgamation of his life experiences. One of Sapto's works emphasizes the use of computers to generate samplings of gamelan sounds and patterns. In a performance that I saw at the 1996 festival, he performed his piece, standing up and hopping around the front of the stage, playing an electric keyboard to retrieve or respond to sampled gamelan sounds, which emanated from a computer in front of him. Behind him was a complete set of gamelan. While Sapto was playing his electric keyboard, other musicians entered the stage, one by one, each sitting down and starting to play an instrument of his choice. Playing kendhang, demung, kenong, and kempul, each musician responded 'freely' to Sapto's melodies.

The late Cokrowasito (1909-2007), known intimately as Pak Cokro, was teaching gamelan at the California Institute of the Arts from 1971 until his retirement in 1992. When he lived in Yogyakarta, he was known as one of the most active musicians, directing the gamelan ensembles at the Radio of the Republic of Indonesia (Radio Republik Indonesia, RRI) and the Paku Alam court, and composing traditional and new gamelan pieces. His work is sometimes categorized as kreasi baru (new creation), the new work drawn largely from traditional musical idioms. At the 1994 FKY, he presented Jaya Manggala Gita (JMG, Song of triumph). This piece portrays a history of Java from the 12th-century King Erlangga until the independence of Indonesia in the 1940 s. $^{16}$ The ensemble for JMG comprises a complete gamelan plus the archaic Monggang and Kodhok Ngorek ensembles. The combined ensemble has more than one rebab and gender. The music consists of a sequencing of different gendhing and/or different

16 JMG is an important topic of Becker's seminal work (Becker 1980). She points out that through his works, Cokrowasito can be seen as a modern pujangga (poet and chronicler in Javanese court) in modern Java. 
ensembles. Each period of history is portrayed by different pieces or different ensembles. In this sense, JMG is a narrative with song-texts describing each historical period. Although JMG includes new pieces composed by Cokrowasito, several traditional gendhing are also an integral part of the composition. Whether new gendhing or not, all are composed in traditional gamelan structure and idioms. There are only two non-traditional elements in JMG: a Western-style chorus with multiple parts, and a conductor, who conducts the ensemble in the manner of a Western conductor. In a previous performance of JMG that I saw in 1970, Cokrowasito himself conducted the ensemble.

Slamet Abdul Sjukur is one of the most prominent Indonesian composers today. He began in the 1950s as a student at the Indonesian Music School (Sekolah Musik Indonesia, SMI) in Yogyakarta before continuing his musical training in Paris in the 1960s. His teachers there included Messiaen and Dutileux (Mack 1995: 552). In 1972, Sjukur returned to Indonesia to teach and direct a music programme at the Jakarta Institute of the Arts (Lembaga Pendidikan Kesenian Jakarta, LPKJ), and compose. In 1982, he became an independent composer living in Surabaya. He defines his music as 'Minimax', music that uses minimal sources maximally (Mack 1995: 570). He comments: 'It seems that not too many people in the musical circle are interested in this kind of approach. We are already used to aiming at high [complex] aspirations, and it is not possible anymore for us to understand about things as they are, let alone to cultivate the kind of potential that is inherent in the plainness and simplicity' (Sjukur, quoted in Mack 1995: 570). ${ }^{17}$

As exemplified by the works of the composers described above, hybrid music of various genres typify YGF programming. Hybridizing 'ethnic' with Western music is the main feature of the festival's music. Such mixtures raise the interest of the younger audience, who think of traditional music such as gamelan music as old fashioned, conservative, and 'out of step with the world'. For them, music will be 'in step with the world' if it is mixed with Western music.

The presence of music groups from abroad increases the prestige of YGF. These foreign groups also offer a variety of hybrid genres. For example, the Australian GengGong ensemble blends musical idioms from Java, the

17 My own translation. 
Middle East, Bulgaria, Sumatra, and Turkey ${ }^{18}$ - the diverse backgrounds of its members reflect this regional variety; the group is led by a former Indonesian rock star, guitarist Sawo Jabung. In a performance I saw at the festival in 2007, their use of bonang to play excerpts of Javanese folk melodies, and their featuring of Sundanese drumming performed by Ron Reeves (one of the group's percussionists) were of special interest to the audience.

Ensemble Gending from the Netherlands also presents hybrid music of a different character. The group was founded in 1988 and is named after a composition of the same name, composed in 1975 by Ton de Leeuw. The piece uses a slendro gamelan but, following the tradition of Western art music, de Leeuw wrote a complete score for different parts of the gamelan, and a conductor was employed for the performance. In this case, the hybrid nature of the music lies in the use of Javanese gamelan instruments to play a composition composed and performed in the manner of Western art music. This seems to follow De Leeuw's desire 'to write new music, with respect for the instrumental organism, but without leaning on traditional Javan ways of thinking' (Van der Vliet n.d.). However, he also recognizes the intentional or unintentional borrowing of Javanese musical concepts (De Groot and Sligter 1995) ${ }^{19}$ In the performance I witnessed at the 1997 festival, the audience was delighted by the dynamics of the music, which was conveyed by changes of musical textures (e.g. from playing a thin texture produced by one or two instruments, to a thick texture of several instruments played together). A couple of times the Javanese audience broke into excited applause when a sudden and drastic textural change occurred.

To sum up, the emphasis on the hybridizing of different music ensembles, instruments, idiom, genres, and music technology, especially between Indonesian and European kinds of music, is characteristic for the YGF. This emphasis characterizes the other hybrid music.

18 GengGong's website, http://home.iprimus.com.au/wot/intro.htm.

19 De Groot and Sligter point out that in composing Gending, De Leeuw lists a threelevel process of acculturation: material, structural, and mental. The material level is a result of the use of eastern instruments, while the structural level is a consequence of an intentional borrowing of Javanese structural principles. He considers the mental level the most important. It is derived from a cyclic conception of time, a slow musical respiration, a tendency to not dramatize. 


\section{A Controversy: Campursari}

Another recent type of Javanese-Western hybrid music is campursari (a mix of essences). The campursari ensemble consists of both gamelan and Western instruments. Featuring electronic keyboards, campursari performs light pieces from the gamelan repertoire and pieces from other genres of popular music. Although it developed in the 196os, it experienced a surge in popularity in the mid-199os.

There has been a great deal of positive and negative discussion about campursari, which attempts to understand its domination of Javanese musical life. The debate often intensifies in light of noticeable musical conflicts found in the genre, in particular an incompatibility between Western diatonic-based pentatonic scales and a pentatonic gamelan tuning system. Although a few campursari groups tune their gamelan to match a diatonic Western scale, other groups are not concerned about this tuning incompatibility (which results in a musical presentation in which the instruments and singers are not in tune with one other). Mrázek (1999: 67) suggests that this incompatibility, combined with other elements, is a kind of metaphor for conflict in the present world. In campursari, many people 'listen to gamelan instruments and techniques, and they listen to the keyboard and other non-gamelan instruments at the same time, but not to their not-being-in-tune. They try to ignore the wholeness of the whole, because the whole lacks wholeness. The result is a kind of selective listening, listening that separates and often does not put things together, but rather keeps them separate, and enjoys them separately, though at the same time.'

Similar to Mrázek's suggestion, Rahayu Supanggah (2003: 15-16) sees the 'clashes' in campursari as a reflection of larger socio-cultural problems caused by modernization. Supanggah explains:

Interestingly, the mingling and clashing of cultural and musical conventions, and the number of different people involved is not such a problem for the community of campur sari artists, nor for the supporting community of audience, listeners and sponsors. They do not feel disturbed or uncomfortable with these clashes. The campur sari community accepts the music openly, and with pleasure and sincerity. They consider that everything happens naturally. Some people recognize that campur sari is a work of art, a product of creativity of a group of artists. Campur sari can also be considered as a collective attempt to save one or more musical genres. Without (the help of ) campur sari, it is believed that one of the above musical genres could die out (Rahayu Supanggah 2003: 14). 
Sutton (2002: 27-28) observes that, according to a number of younger musicians, campursari is helping to preserve Javanese gamelan tradition by incorporating Javanese instruments and singing styles in a genre that is modern and popular. As they see it, vast numbers of Javanese, particularly younger ones, enjoy and consume this music (live and through the media) who would otherwise be listening to Western pop or its Indonesian imitations. Better a compromised Javanese music than none at all, perhaps?' But Sutton's older teachers and acquaintances offered just the opposite interpretation. They claimed:

[...] that campur sari is as great a threat to the gamelan tradition they know as is Western-style pop music. For campur sari emphasizes a pop, commercial ethos and takes the place of more traditional gamelan playing (of much higher artistic value, they would say) in village and family rituals, not to mention in the regional cassette industry. Thus, in the opinion of these knowledgeable and concerned individuals, campur sari does popularize some aspects of the indigenous, but at the same time severely compromises the indigenous tradition on which it draws. While it may sustain a certain repertory of light pieces, an appreciation for a distinctly Javanese vocal style, and an acceptance of Javanese gamelan instrumentation and timbre, it transforms and quite literally replaces other indigenous practices - rather than popularizing them (Sutton 2002: 28).

Perlman (1999: 10) suggests a different view on campursari. He says that '[c]ampursari may prove to have little to do with tuning systems. Campursari may be more interesting as a symptom of the emergence of a broad musical borderland, where the lightest parts of the gamelan repertory mingle with kroncong, langgam Jawa, dangdut, and even Indonesian pop songs'. Certainly, this is the primary reason for the widespread fame of campursari, i.e. its focus on light, popular pieces; so much so that the conflict in tuning systems is largely ignored by its fans.

The many views on campursari reflect the intrigue surrounding this genre. In the last three decades, this music has experienced an astonishing development; it has earned its fame from live performances within wide-ranging contexts. Campursari is also a mass-mediated music. It has been widely disseminated on cassette, CD and VCD. There have been many campursari festivals and competitions. Television programmes periodically broadcast campursari in the form of a music programme that includes audience members and the viewers at home making musical requests. These all contribute to the strength of the genre in generating economic wealth for its creators and producers. This success has created a feeling of resentment among traditional gamelan players. They complain 
that, with the capital of only a few instruments and a repertoire of light pieces, campursari produces wealth and fame.

My discussion of music performed at the YGF and campursari suggests that since the 1980 s Indonesia has been saturated with the notion of modernizing gamelan through hybridizing it with Western music. I suggest that this atmosphere of modernizing gamelan indirectly contributed to the decision to use gendhing mares in bedhaya Semang.

\section{Conclusion}

In discussing the Hinduization of Southeast Asia, Wolters (1999: 55) states that 'Indian material tended to be fractured and restated and therefore drained their original significance [...]. The materials [...] had to be localized in different ways before they could fit into various local complexes or religious, social, and political systems and belong to [a] new cultural "whole." Only when this happened would the fragments make sense in their new ambiences.'

The localization process referred to by Wolters fits any process of localization in any historical period. It should be kept in mind, however, that in each region (or even within a region) the process bears out quite different results; hence, the heterogeneity of both the result and process of cultural domestication. In the case of tanjidor, a Western brass ensemble was localized to the extent that European music had become Sundanese music. On the other hand, gendhing mares played out differently than tanjidor. Here, the Javanese did not substantively localize European music, but the end-result is symbolically very rich. The development of these cultural performances was interdependent with the life of European traders (for tanjidor), central Javanese courtiers (for gendhing mares), and colonialism. Beginning in the mid-twentieth century, Indonesian government and private institutions took over these tasks.

In the early part of the twentieth century, we learn of the increasing exposure of Indonesian people to Western music, especially popular genres. Films, radio, and the phonograph contributed to the wide dissemination of Western music and cassette technology expedited the expansion of Western popular music. These developments inspired the emergence of different forms of Western-based Indonesian popular music. Although the spread of Western popular music was temporarily halted during the Sukarno regime, during the New Order period under Suharto's regime Western commercial popular culture and all kinds of Western music 
genres flooded Indonesia. Indonesian popular music was reinvigorated, and new popular musical genres emerged.

This development shaped the character of hybridization, pushing toward the mixing of traditional music with Western music; hence, the emergence of all sorts of Western-Indonesian music styles and genres, such as campursari and music presented at the Yogyakarta Gamelan Festival. Regarding gendhing mares, this musical genre marks a special distinction in the repertoire of Yogyakarta court gamelan, a source of pride to the courtiers there. The prevalent atmosphere of Javanese-Western musical hybridity since the 1980 s has contributed to the decision of using gendhing mares in the performance of bedhaya Semang in 2006. In this sense, gendhing mares is conceived as both a special musical distinction of the court of Yogyakarta and a genre that is in step with contemporary musical development.

\section{References}

Abdurachman, Paramita R. Bunga angin Portugis di Nusantara:Jejak-jejak kebudayaan Portugis di Indonesia. Jakarta: LIPI Press/Asosiasi Persahabatan dan Kerjasama IndonesiaPortugal/Yayasan Obor Indonesia, 2008.

Anderson Sutton, R. 'Popularizing the indigenous or indigenizing the popular? Television, video and fusion music in Indonesia', Wacana Seni: Journal of Arts Discourse 1: 13-31, 2002.

Atmadikrama, R. 'Babad Krama Dalem Ingkang Sinuhun Kangjeng Susuhunan Paku Buwana Kaping Sanga ing Nagari Surakarta Adiningrat'. [Manuscript inscribed Surakarta, mid-late 19th century.] 1865-1866.

Becker, Judith. Traditional music in modern Java: Gamelan in a changing society. Honolulu: University of Hawaii Press, 1980.

—. 'Earth, fire, śakti, and the Javanese gamelan', Ethnomusicology 32-3: 385-391, 1988.

Boxer, C.R. The Dutch seaborne empire, 160o-180o. New York: Knopf, 1965.

Ferianto, Djaduk. Orkes Sumpeg. Yogyakarta: Studio Tari Bagong Kussudiardja. [Liner notes Cassette recording.] 1997.

Geertz, Clifford. The interpretation of culture: Selected essays. New York: Basic Books, 1973.

Groneman, J. De gamelan te Jogjakarta. Amsterdam: Johannes Müller, 1890.

Groot, Rokus de and Jurrien Sligter. 'Introduction', in: Jurrien Sligter (ed.), Ton de Leeuw, pp. xiii-xxvii. Luxembourg: Harwood Academic Publishers, 1995.

Haan, F. de. Priangan: De Preanger-Regentschappen onder het Nederlandsch bestuur tot 1811. Volume 4. Batavia: Kolff; 's-Gravenhage: Nijhoff, 1910/12.

Haryadi, Frans et al. Tanjidor: Sebuah laporan pengamatan lapangan kesenian tanjidor di daerah Jakarta dan sekitarnya, Mei-Oktober 1979. Jakarta: Lembaga Pendidikan Kesenian Jakarta, Departemen Tari, 1980.

Hostetler, Jane. 'Bedhaya Semang: The sacred dance of Yogyakarta', Archipel 24-1: 127-142, 1982.

Lindsay, Jennifer. Klasik, kitsch, kontemporer: Sebuah studi tentang seni pertunjukan Jawa. Yogyakarta: Gadjah Mada University Press, 1991.

Mack, Dieter. Sejarah musik. Volume 4. Yogyakarta: Pusat Musik Liturgi, 1995. 
Mrázek, Jan. 'Javanese wayang kulit in the times of comedy: Clown scenes, innovation, and the performance's being in the present world'. Part One, Indonesia 68: 38-128, 1999.

Pemberton, John. On the subject of 'Java'. Ithaca, NY: Cornell University Press, 1994.

Perlman, Marc. 'The traditional Javanese performing arts in the twilight of the New Order: Two letters from Solo', Indonesia 68: 1-37, 1999.

Poedjosoedarmo, Soepomo and M.C. Ricklefs. 'The establishment of Surakarta: A translation from the Babad Gianti', Indonesia 4: 88-108, 1967.

Rice, Timothy. 'Toward the remodeling of ethnomusicology', Ethnomusicology 31-3: 469$488,1987$.

Ricklefs, M.C. A history of modern Indonesia since c. 1300. 2nd ed. Stanford, CA.: Stanford University Press, 1993.

Serat Pakem Wirama. 'Serat Pakem Wirama Wileting Gendhing Pradangga'. [Javanese manuscript, first written in 1889 and transcribed in Latin in 1934.] 1889-1930s.

Subuh. 'Gendhing-gendhing mares atau gati Kraton Yogyakarta'. BA thesis, Institut Seni Indonesia, Yogyakarta, 1986.

Suharti, Theresia. 'Bedhaya Semang: Dimensi spiritual dinasti kesultanan Yogyakarta. Sebuah karya rekonstruksi', Seni. Jurnal Pengetahuan dan Penciptaan Seni 9-1: $38^{-52}$, 2002.

Sumarsam. Gamelan: Cultural interaction and musical development in Central Java. Chicago: University of Chicago Press, 1995.

_ . 'Indonesia: History', in: Stanley Sadie and John Tyrrell (eds), The New Grove Dictionary of Music and Musicians, pp. 283-286. 2nd edition. Volume 12. Oxford and New York: Oxford University Press, 2001.

Supanggah, Rahayu. 'Campur sari: A reflection', Asian Music 34-2: 1-20, 2003.

Vetter, Roger R. 'Music for "the lap of the world": Gamelan performance, performers, and repertoire in the Kraton Yogyakarta'. PhD dissertation, University of Wisconsin, Madison, 1986.

Vliet, Leontien van der. Ensemble Gending: Jurrien Sligter. Netherlands: NM Classic. [Liner notes of CD; English translation Rob Stuart]. n.d.

Wall, V.I. van de. Indische landhuizen en hun geschiedenis. Batavia: Koninklijk Bataviaasch Genootschap van Kunsten en Wetenschappen, 1932.

Wolters, Olivier. History, culture, and region in Southeast Asian perspectives. Revised edition. Ithaca, NY: Southeast Asia Program, Cornell University, 1999.

Yampolsky, Philip. Betawi \& Sundanese music of the North Coast of Java: Topeng Betawi, Tanjidor, Ajeng. Washington DC: Smithsonian/Folkways. [Booklet accompanying CD.] 1994.

Zoetmulder, P.J. Old Javanese-English Dictionary. Volume 1. 's Gravenhage: Nijhoff, 1982. 